\title{
Gary H. Toops In Memoriam
}

Gary H. Toops passed away this fall, on 14 October 2013. He was born on 30 March 1954 in Fort Eustis, Virginia. He graduated from McGill University in Montreal and earned his $\mathrm{PhD}$ in Slavic languages and literatures from Yale University in 1985. From 1989 he taught at Wichita State University, where he was Professor of Russian and Linguistics. He was the backbone of Wichita State University's Russian program, teaching courses in Russian language, literature, and linguistics, as well as German, French, and general and Romance linguistics.

Professor Toops was also an accomplished Slavic linguist, and he published research articles steadily throughout his career, mostly on Slavic verbal categories. His dissertation is entitled Grammatical Causality in Slavic and remains, as far as I am aware, the only investigation of causal constructions with a cross-Slavic emphasis. Causality and causal auxiliaries in the Slavic languages continued to be a subject of his published articles until his death. His later articles on the subject focused on West Slavic, and his last published article (Toops 2013) presents a detailed comparative analysis of types of causative constructions in Upper Sorbian and Czech.

Professor Toops was also one of the world's leading experts on the Upper Sorbian language, and as time went on most of his research on causality and verbal aspect focused on Upper Sorbian, either exclusively or comparatively. He knew German fluently, which is a necessity for analyses of the grammatical categories of Upper Sorbian (and West Slavic more generally), and much of his later research tackled the issue of German linguistic interference in Upper Sorbian and Czech (see, e.g., Toops 1992a, 1992b, 1999, 2006, 2013). He took a nuanced approach to such German interference, concluding that in some cases German interference could facilitate a change in Upper Sorbian or Czech that then took a path largely determined by the structure of the replicating language itself. His rejection of an either-or approach to German linguistic interference in West Slavic is eminently realistic. 
Toops 2006 is also notable for surveying cases of possible German linguistic interference in Upper Sorbian and ranking them according to degrees of likelihood. This article makes an important contribution to the ongoing assessment of the role of German linguistic influence in western Slavic languages (cf. in this regard similar efforts by Berger [2008] and Reindl [2005]).

One case of German interference in Upper Sorbian aspectual prefixation has, as far as I am aware, been placed in the wider context of the contact-induced breakdown of the Upper Sorbian aspectual system solely in the analysis presented by Toops (1992a). This is the loss of derived imperfectives paired with prefixed perfective verbs of motion and their replacement by constructions of the simplex imperfective plus adverb. For example, perfective wunć 'go out' is no longer paired with the derived imperfective 'wuchadźeć 'idem', but with the imperfective simplex won hić 'out go'. Toops (1992a: 13) points out that the replacement of derived imperfectives has only occurred in the directly spatial meaning of the prefixed verbs of motion, and that in figurative meanings the derived imperfective verbs are still employed (e.g., Nowiny wuchadźeja tydźensce 'The newspaper comes out weekly'). The significance of this development for theories of aspect and aspectual prefixation has not yet been recognized. Note that Toops (2001) also treats similar phenomena in Latvian. It is possible that such "paraphrastic imperfectives" are characteristic of proto-aspectual systems or aspectual systems otherwise characterized by a low degree of grammaticalization. This phenomenon deserves more attention, as it is very relevant for the synchronic and diachronic analysis of Slavic verbal aspect (and, again, the issue of German interference). It is sad that Professor Toops is no longer with us to contribute to the study of this phenomenon.

In general, Professor Toops's work on causatives and verbal aspect is marked by meticulous attention to sometimes subtle discourse factors and never slips into convenient, reductivist arguments. This is one reason why his articles will not lose their relevance for the study of the Slavic verb in the foreseeable future.

It should be noted that Professor Toops translated Heinz SchusterŠewc's Gramatika hornjoserbskeje rěče: Fonomatika a morfologija into English, which allows generalists an insight into this language.

Lastly I would point out that Professor Toops's writings consistently display careful attention to style and terminological precision 
and have always been a pleasure to read. His impeccable use of Latin grammatical terminology somehow emanates a love of and respect for linguistic tradition without being distracting. With this in mind, I will close with the following wish: Requiescat in pace.

\section{References}

Berger, Tilman. (2008) "Deutsche Einflüsse auf das grammatische System des Tschechischen". Studien zur historischen Grammatik des Tschechischen. Bohemistische Beiträge zur Kontaktlinguistik. Munich: Lincom Europa, 57-69.

Reindl, Donald F. (2005) The effects of historical German-Slovene language contact on the Slovene language. PhD dissertation, Indiana University.

Schuster-Šewc, Heinz. (1996) Grammar of the Upper Sorbian language: Phonology and morphology. Gary H. Toops, trans. Munich: Lincom Europa.

Toops, Gary H. (1985) Grammatical causativity in Slavic. PhD dissertation, Yale University.

- (1992a) "Causativity in Czech: The verbs dá(va)t and nech(áv)at". Canadian Slavonic papers 34(1-2): 39-56.

_. (1992b) "Lexicalisation of Upper Sorbian preverbs: Temporalaspectual ramifications and the delimitation of German influence". Germano-Slavica 7(2): 3-22.

. (1999) "Syntactic calquing: Reflections of German verb governance in Czech and Upper Sorbian". Die Welt der Slaven 44(2): 271-84.

(2001) "The grammar of 'paraphrastic imperfectives' in Latvian and Upper Sorbian". Slavic and east European journal 45(1): 96-113.

. (2006) "A contrastive perspective on several morphosyntactic features of Upper Sorbian". Canadian Slavonic papers 48(1-2): 13755 .

. (2009) "On contrasting the use of tense and aspect in Upper and Lower Sorbian". Lenka Scholze and Björn Wiemer, eds. Von Zuständen, Dynamik, und Veränderung bei Pygmäen und Giganten. Bochum: Universitätsverlag Dr. N. Brockmeyer, 95-108. 
Toops, Gary H. (2013) "The morphosyntax of causative relations in Czech and Upper Sorbian: A contrastive, descriptive analysis". Slavonic and east European review 91(3): 401-30.

\author{
Stephen M. Dickey \\ Department of Slavic Languages and Literatures \\ University of Kansas \\ 1445 Jayhawk Boulevard, Room 2128 \\ Lawrence, KS 66045-7594 USA \\ smd@ku.edu
}

